\title{
Thermal tar cracking enhanced by cold plasma - a study of naphthalene as tar surrogate
}

\author{
Yamid Gomez-Rueda ${ }^{a}$, Ilman Nuran Zainic, Weihong Yang ${ }^{c}$, Lieve Helsen a,b \\ ${ }^{a}$ Department of Mechanical Engineering, Celestijnenlaan 300, Leuven 3001, Belgium \\ ${ }^{b}$ Energyville, Thor Park, Waterschei, Belgium \\ ${ }^{c}$ Department of Materials Science and Engineering, KTH Royal Institute of Technology, \\ 10044 Stockholm, Sweden
}

\begin{abstract}
Gasification has been proposed as a good solution for recovering energy from waste and biomass in the form of syngas. However, the presence of tar limits syngas applications. Tar model molecules have been removed by cold plasmas up to $400^{\circ} \mathrm{C}$, but to avoid syngas cooling tar removal above $600^{\circ} \mathrm{C}$ is required. To investigate tar removal by cold plasma at higher temperatures, two sets of experiments were done, one to identify tar composition from MSW gasification, and a second one to crack in a nanosecond-pulsed corona plasma at high temperatures the most refractory tar compound found, naphthalene. In this paper, we report the first results of cold plasma for tar cracking at temperatures up to $1100^{\circ} \mathrm{C}$, revealing that this tandem can remove naphthalene completely at $800^{\circ} \mathrm{C}$, compared to the $1000^{\circ} \mathrm{C}$ needed in case of thermal cracking alone. The synergy between plasma and thermal cracking is driven by higher energy densities when temperatures increase. However, this synergy stops when thermal cracking reactions predominate.

Keywords: Gasification, Municipal Solid Waste, Cold Plasma, Tar

Removal, Naphthalene
\end{abstract}




\section{Introduction}

Tar is a set of substances produced as a byproduct during the gasification of carbon-rich feedstock, such as Municipal Solid Waste (MSW), and its removal from syngas has been identified as one of the major challenges in gasification [1]. Although tar is a major factor in environmental pollution from gasification due to its toxic nature $[2,3]$, the main operational problem associated with tar is its capacity of condensing at high temperatures, which eventually causes clogging of piping and equipment, increasing maintenance times to inadmissible levels [4]. These maintenance times are critical for appliances such as gas turbines and engines, where the small injectors are prone to be blocked. Tar can also cause the deactivation of catalysts by coking, which hampers tar-polluted syngas to be used in fuel cells $[5,6,7,8]$, in methanation [9] and in Fischer-Tropsch synthesis.

Although there are some methods that take advantage of the ease of tar condensation to remove them, it is preferred to crack them to produce more syngas to avoid cooling (which is needed for condensation) in order to recover the sensible heat contained in the syngas. Cooling should be avoided if the downstream valorization processes are also carried out at high temperatures, such as in the case of methanation (operating at $500-700^{\circ} \mathrm{C}$ ) [10] or Solid Oxide Fuel Cells (SOFCs operating between $750-950^{\circ} \mathrm{C}$ ) [11]. Even if the subsequent valorization is carried out at lower temperatures, such as in Fischer-Tropsch or Proton-Exchange Membranes (PEM) fuel cells, cracking tar at the high temperature of the gasifier outlet is still beneficial since tar cracking reactions are endothermic.

So far, thermal and catalytic cracking have shown to be able to remove 
tar to a high extent but the use of excessive temperatures in the former case (usually above $1000-1250^{\circ} \mathrm{C}$ ) $[12,13,14,15]$, and the short lifetime due to coking [16], sulfur [17] or evaporation for the latter case does not allow them to be used extensively in the industry [18]. Some alternative approaches, like the addition of activated carbons and biochar, can be effectively used in certain lab conditions for tar removal [19, 20, 21], but not in real large-scale gasifiers due to carbon consumption by steam and oxygen reactions.

Therefore, plasma has arisen as a new solution for tar cracking. Thermal plasmas, which exhibit high temperatures (above 4000K) have been extensively used for MSW gasification in primary units $[22,23,24,25,26]$ but also in secondary units for tar cracking. Materazzi et al. [27] have demonstrated that a thermal plasma secondary unit can convert tar into CO instead of soot, by using a plasma torch operating in a temperature range of $5500--10,000^{\circ} \mathrm{C}$. It has also been reported that the high temperatures alone are not able to remove some tar components such as naphthalene and benzene; naphthalene and benzene removal needs the combined effect of plasma excited species and high-temperature [28].

Although tar has been successfully removed with thermal-plasmas, the energy demand of such plasmas is large, making this technology feasible only when electricity is extremely cheap, or when difficult-to-treat inputs (such as dangerous waste) is used as feedstock [29]. For instance, Marias et al. [30] determined that a plasma torch of $240 \mathrm{~kW}$ needed to produce a syngas with a power of $1616 \mathrm{~kW}$, which is an enormous amount of high quality energy (electricity) needed as input. The extreme gas heating up in thermal plasma cracking might require as well extra cooling down of the producer 
gas for downstream applications. This has opened a window for using delete intensive plasmas, such as warm and cold plasmas which are less heated.

The main difference between cold plasmas and thermal plasmas is the equilibrium temperature of the plasma species. While in thermal plasmas all species are in thermal equilibrium, in cold plasmas the electron temperature is higher than the temperature of the other species. This means that the gas is not heated-up by the plasma, but it is still exposed to high-energy electrons, generating excited molecules, ions, and UV radiation. In the case of warm plasmas, there is still a non-equilibrium temperature among all the species, but some degree of heating is achieved. In tar cracking, Dielectric Barrier Discharge (DBD) and corona plasmas are the main cold plasma technologies used, and gliding arc discharge (GAD) is the main warm-plasma technology used.

Although GADs have shown to be effective for tar model compounds removal alone $[10,31,32,33,34]$ or in combination with catalysts [35, 36, 37], the need of syngas cooling after such units is still there. However, by using cold plasmas (DBD and corona) there is a negligible gas heating, discarding the need of any downstream syngas cooling.

The main difference between the two cold plasma technologies mentioned lies in the type of voltage source used: while DBD uses AC, corona uses DC. This has many implications, one is that while DBD plasmas need a dielectric material around one or two of the electrodes, corona plasmas do not need any dielectric. Unfortunately, corona plasmas can easily transit towards a spark and are more difficult to control. The other main difference is that DBD plasmas are naturally pulsed due to the AC energy source, while 
corona plasmas need an extra unit in order to generate a pulsed discharge.

DBD plasma units have been the most explored cold plasma technologies in lab-scale experiments for tar removal, either alone or in combination with catalysts. Although some authors have studied the DBD plasma alone, like Saleem et al. [38], for the removal of benzene, or Wu et al. [39] in the removal of naphthalene, most of the studies have been performed using plasma in combination with catalysts. For instance, Liu et al. showed that an M1Al3 catalyst in a plasma reactor can achieve toluene conversions higher than 95\% with benzene and ethylbenzene as main reaction products [40]. Similar works using a plasma combined with in-situ $\mathrm{Ni} / \mathrm{Al}_{2} \mathrm{O}_{3}$ and $\mathrm{Ni} / \mathrm{ZSM}$ show an enhanced conversion of toluene with a simultaneous soot reduction $[41$, 42] when compared to plasma cracking alone. Naphthalene has been also successfully removed in similar plasma-catalytic systems [36, 43, 44].

Corona plasmas have been used in few cases for the conversion of naphthalene and hydrocarbons. Nair et al. were able to remove naphthalene at $400^{\circ} \mathrm{C}$ at residence times of $3 \mathrm{~min}$ [45] and Bityurin et al. demonstrated that carbon monoxide reduced naphthalene cracking activity when compared to a pure nitrogen atmosphere [46]. The reduced use of corona plasma with respect to DBD is due to the difficult generation of pulses, which requires the use of high voltage resistors to limit the current, requiring careful design to avoid sparks in the HV system. However, the lack of any dielectric material in corona plasmas makes them interesting for using them at the high temperatures found at the exit of gasifiers.

However, removing tar at low temperatures has very little advantage in comparison to wet scrubbing using organic solvents (except that liquid waste 
streams are avoided), because it forces the gas exiting the gasifier to be cooled-down for cleaning, requiring a reheating after the cleaning process for ultimate valorization. So far the highest reported operating temperature on which a cold-plasma cracking unit has operated is $400^{\circ} \mathrm{C}$ for corona plasma [45] and $400^{\circ} \mathrm{C}$ for DBD plasmas [47].

There is thus a need for operating cold plasma systems at higher temperatures. In this paper, two sets of experiments are described in order to evaluate a nanosecond pulsed corona plasma for tar removal at high temperatures. The first set of experiments focused on the characterization of tar resulting from gasification of MSW from steam and air atmospheres. In this analysis it is used the standard definition of tar given by the EU/IEA/USDOE panel, which considers as tar as all the organic compounds of a higher molecular weight than benzene [48], and it is also used the tar classification made by the Energy Research Center of the Netherlands (ECN) [49] showed in table 1 in order to understand tar evolution. The second set of experiments focused on cracking the most stable tar molecule identified in the first part in a nanosecond pulsed corona plasma under a nitrogen atmosphere.

\section{Experimental}

The feedstock for the first set of experiments was a MSW sample with the fraction and composition given in table 2. The gasification reactor consists of a stainless-steel 316 cylinder with two temperature zones, one cold and one hot. The MSW sample was kept in the cold zone, around $20^{\circ} \mathrm{C}$, while the hot zone of the reactor reached the desired temperature. The reactor was kept under a flow of $\mathrm{N}_{2}$ while heating-up. The sample was then moved to the 
Table 1: Tar compound classification according to ECN [49]. Acronyms: GC $=$ Gas Chromatography, PAH = Polyaromatic Hydrocarbons.

\begin{tabular}{llll}
\hline \hline Nomenclature & Description & Properties & Representative compounds \\
\hline \hline Class 1 & GC-undetectable & Very heavy tar; undetectable by GC & $\begin{array}{l}\text { Biomass fragments; } \\
\text { heaviest tar }\end{array}$ \\
\hline \multirow{2}{*}{ Class 2} & Heterocyclic aromatics & $\begin{array}{l}\text { Tar containing hetero atoms; } \\
\text { highly water soluble }\end{array}$ & $\begin{array}{l}\text { Pyridine, phenol, quinoline, } \\
\text { isoquinoline, cresols }\end{array}$ \\
\hline \multirow{2}{*}{ Class 3} & Light aromatic & Light hydrocarbons; do not pose & Toluene, ethylbenzene, \\
& $(1$ ring $)$ & condensation or solubility problems & xylenes, styrene \\
\hline \multirow{2}{*}{ Class 4} & Light PAH compunds & Condense at intermediate & Indene, naphthalene, \\
& $(2-3$ rings $)$ & temperatures at high concentrations & $\begin{array}{l}\text { methylnaphthalene, } \\
\text { phenanthrene, anthracene }\end{array}$ \\
\hline \multirow{2}{*}{ Class 5} & Heavy PAH compunds & Condense at high temperatures & Fluoranthene, pyrene \\
& $(\geq 4$ rings $)$ & even at low concentrations & crysene,perylene, coronene \\
\hline \hline
\end{tabular}

hot-zone and kept under a flow of air for $60 \mathrm{~min}$, with an Equivalence Ratio (ER) of 0.3 for air gasification experiments with and air flow of $95 \mathrm{ml} / \mathrm{min}$ and a steam-to-waste ratio of 0.5 for steam gasification experiments.

The sample weight during all the experiments was $5 \mathrm{~g}$. The steam was injected by a boiler unit connected by a three-way valve to the main reactor. The steam was injected once the boiler steady-state was reached and checked by measuring the steam condensation in a parallel process. The tar generated was sampled by the Solid-phase Adsorption - Solid-phase Extraction (SPA/SPE) method as stated by Brage et al. [50] and the gas released was collected in a Tedlar-gas bag for being analyzed off-line by a micro-GC. A scheme of the experimental setup is presented in figure 1.

For the second part of the experiments, only one tar model molecule was chosen based on the results of the first series of experiments. The equipment 


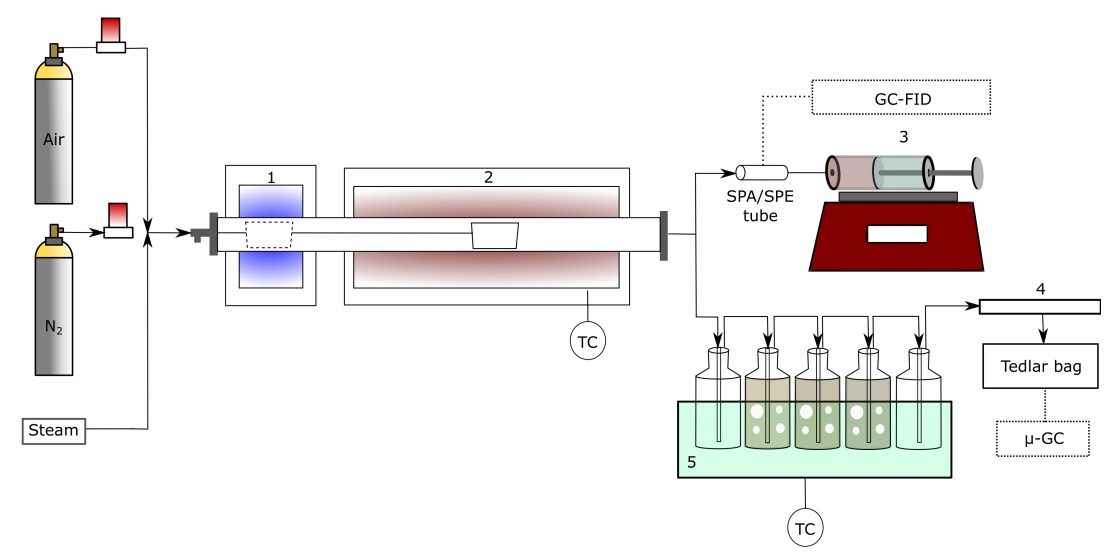

Figure 1: Gasification reactor. Parts: 1. Reactor cold zone. 2. Reactor hot-zone. 3. SPA/SPE sampling setup 4. Glass wool filter. 5. Series of bottles for tar condensation, three of them contain acetone while the other two are empty.

used in this part consists of a High-Voltage Direct-current (HV DC) power unit with $24 \mathrm{kV}$ voltage and $5 \mathrm{~mA}$ current connected to an RC-circuit which allows producing short DC pulses by using a spark-gap switch filled-up with nitrogen. The pulses are then transmitted through a coaxial cable to a reactor that is placed inside a three-zone oven. The reactor consist of a FeCrAl pipe of $1.27 \mathrm{~m}$ length and $64 \mathrm{~mm}$ diameter.

Upstream of the reactor, a saturator filled up with the objective molecule is kept at a temperature of $70 \pm 1^{\circ} \mathrm{C}$. A carrier nitrogen stream of $2 \mathrm{NL} / \mathrm{min}$ (normal liter per minute) passes trough the saturator which is mixed-up with a second nitrogen stream of $2 \mathrm{NL} / \mathrm{min}$ before entering the plasma reactor. The residence time in the plasma reactor is set to $30 \mathrm{~s}$ in order to obtain an appreciable energy density (see equation 2). Between each temperature test, the reactor was flushed with air for $20 \mathrm{~min}$ to remove the soot produced and then again purged with nitrogen for $10 \mathrm{~min}$. The tar concentration 
Table 2: Waste fractions, proximate and ultimate analysis of the MSW samples used in gasification tests

\begin{tabular}{|l|l|}
\hline Waste fraction & Fraction (wt\%, dry basis) \\
\hline Wood & 1 \\
\hline Paper & 4 \\
\hline Textile & 9 \\
\hline 2D plastics & 39 \\
\hline 3D plastics & 5 \\
\hline Other combustible & 11 \\
\hline Fines & 31 \\
\hline
\end{tabular}

\begin{tabular}{|l|l|}
\hline \multicolumn{2}{|l|}{ Proximate composition $(\mathbf{w t} . \%, \mathbf{d b})$} \\
\hline Volatile matter & 55.3 \\
\hline Fixed carbon & 1.8 \\
\hline Ash & 46.5 \\
\hline \multicolumn{2}{|l|}{ Ultimate composition (wt.\%, db) } \\
\hline C & 40.5 \\
\hline H & 6.1 \\
\hline N & 1.1 \\
\hline O & 4.3 \\
\hline S & 0.2 \\
\hline Cl & 1.2 \\
\hline LHV $(\mathrm{MJ} / \mathrm{kg}, \mathrm{db})$ & 22.9 \\
\hline
\end{tabular}

was evaluated by the SPA/SPE method, by sampling $100 \mathrm{ml}$ of gas at the bottom of the reactor after each test, with a blank test taken before each test. Between three to five samples were taken for each experiment after 25-30 minutes of achieving steady-state. All gas lines, including the SPA sampling lines, are heated at a temperature between $105-110^{\circ} \mathrm{C}$. A scheme of the experimental setup is shown in figure 2. The plasma discharge was followed by a Handyscope HS4 DIFF from the company TiePie.

\subsection{Performance indicators}

In order to evaluate the thermal-plasma tar removal process, multiple indicators need to be calculated. One of these performance indicators is the energy per pulse delivered by the plasma, which is determined by equation 1 from the voltage-current curves presented in figure 3. 


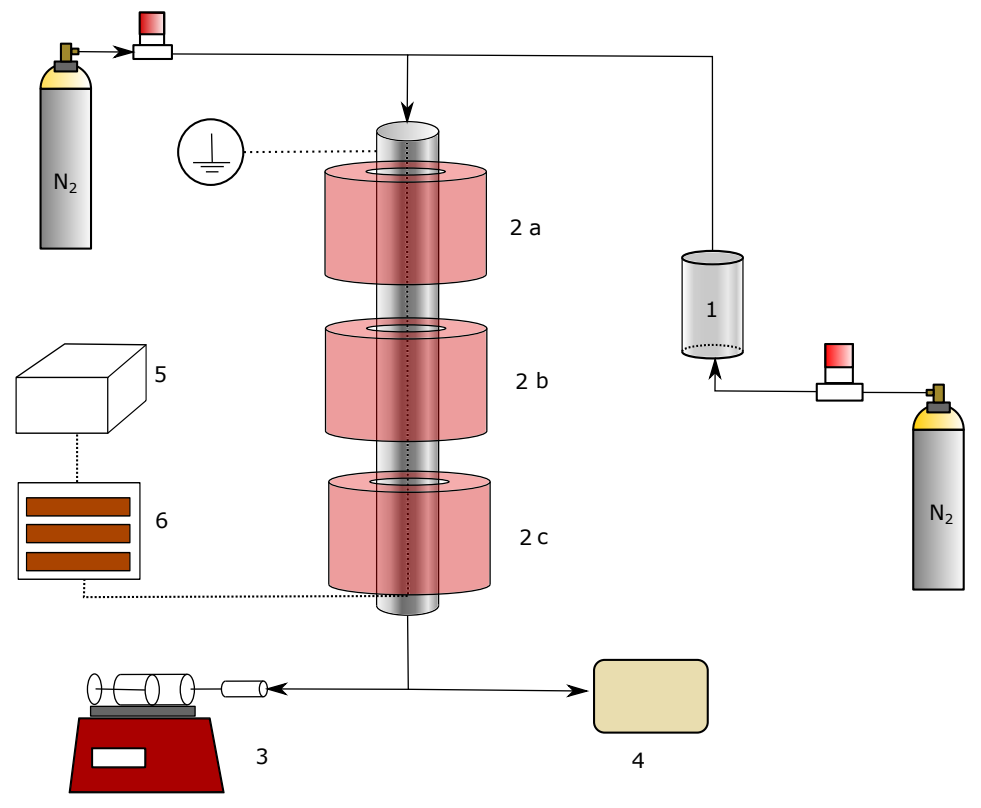

Figure 2: HV nanosecond pulsed corona plasma reactor setup. Parts: 1. Tar model molecule saturator. 2a,b,c. Three-zone convection oven. 3. SPA/SPE sampling 4. Exhaust. 5. HV DC power supply. 6. Pulse generator

$$
E p=\int_{0}^{t=500 n s} U(t) I(t) d t
$$

where $\mathrm{E}_{p}$ is the energy per pulse in $\mathrm{mJ}$ per pulse, $\mathrm{U}(\mathrm{t})$ represents the instantaneous voltage in $\mathrm{V}$ and $\mathrm{I}(\mathrm{t})$ represents the instantaneous current in A. Another parameter for evaluating the tar removal efficiency is the specific energy input (SEI) or energy density, which is calculated using equation 2 where $\mathrm{E}_{p}$ is the energy per pulse determined by equation 1 in mJ per pulse, $\nu$ is the frequency of the pulses in pulses per second, and $\dot{Q}$ is the volumetric flow of nitrogen carrying the tar model molecule in normal liters per minute. The SEI units are $\mathrm{J} / \mathrm{L}$. 


$$
S E I=\frac{E_{p} * \nu * 60}{\dot{Q} * 1000}
$$

The conversion of the tar model molecule in the plasma tar cracking experiments is determined by using equation 3 where $\mathrm{C}_{o}$ represents the initial concentration of the model compound, which was taken when the reactor was heated at $100^{\circ} \mathrm{C}$, while $\mathrm{C}_{f}$ represents the final concentration.

$$
\eta(\%)=\frac{C_{o}-C_{f}}{C_{o}} * 100
$$

The energy efficiency or energy removal efficiency, (EE) of the plasma process is evaluated by equation 4 , where $[\mathrm{C}]_{\text {on }}$ and $[\mathrm{C}]_{\text {off } f}$ are the concentrations leaving the reactor when the corona plasma is on and off respectively,

$$
E E=\frac{[\mathrm{C}]_{\mathrm{off}}-[\mathrm{C}]_{\mathrm{on}}}{S E I}
$$

A final significant parameter is the energy efficiency parameter $\beta$ (also known as characteristic energy or energy cost) of the model molecule destruction process. It is calculated from plotting the exponential decrease of the model molecule concentration versus SEI, as in equation $5[51,52]$ where $\beta$ and the SEI are given in $\mathrm{J} / \mathrm{L}$.

$$
\frac{[\mathrm{C}]_{o n}}{[\mathrm{C}]_{o f f}}=\exp \left(\frac{S E I}{-\beta}\right)
$$

\section{Results and discussion}

\subsection{Identification of tar representative molecules}

The first part of the experiments consists of gasification experiments using air and steam for the light MSW fraction in the setup described in figure 
Table 3: Gasification experimental matrix

\begin{tabular}{|l|l|l|}
\hline Gas agent & Temperature & Sample ID \\
\hline \multirow{2}{*}{ Air } & $800^{\circ} \mathrm{C}$ & Air- 800 \\
\cline { 2 - 3 } & $1100^{\circ} \mathrm{C}$ & Air-1100 \\
\hline \multirow{2}{*}{ Steam } & $800^{\circ} \mathrm{C}$ & Steam- 800 \\
\cline { 2 - 3 } & $1100^{\circ} \mathrm{C}$ & Steam- 1100 \\
\hline
\end{tabular}

1. The experimental matrix is shown in table 3 . The objective of this experimental program is to evaluate the tar speciation at different temperatures and using different gas agents, but also to determine which compounds are more difficult to remove by thermal cracking.

The tar composition of these experiments is presented in tables 4 and 5 which are analyzed with respect to total tar, phenolic compounds concentration, and aromatic compounds distribution. At first sight, the temperature increase causes a reduction in the total tar yield. For air gasification, the effect is evident, but not for steam. Although total tar yield is almost the same in both experiments with steam, at $1100^{\circ} \mathrm{C}$ the presence of benzene is much higher. Considering that benzene is quantified but it does not enter into the definition of tar, then the tar yield reduction is more clear.

Regarding phenolic compounds, presented in table 5, they are present in very low quantities at $800^{\circ} \mathrm{C}$, and totally disappear at $1100^{\circ} \mathrm{C}$. Due to these two reasons, we can leave out of consideration these compounds in the second set of experiments.

The aromatic compounds represent between 97 and $100 \%$ of the total tar yield in all experiments. At $800^{\circ} \mathrm{C}$, besides benzene the two most abun- 
dant compounds are toluene and naphthalene for air and o-xylene, naphthalene and indene for steam. At high temperatures, the most representative molecules are naphthalene and acenaphthylene for air and naphthalene and benzene for steam. In all cases naphthalene appears as one of the most representative tar molecules, especially at high temperatures where it is by far the most abundant compound in both air and steam gasification. This makes naphthalene the most interesting molecule to be chosen for the second part of the experiments, which coincides with previous studies that have chosen naphthalene as tar model molecule in biomass and coal gasification $[35,53,54]$.

Other molecules that can be problematic are the polyaromatic hydrocarbons (PAHs) such as acenaphthylene, phenanthrene, fluoranthene, and pyrene. During the experiments, PAHs compounds concentration increases with temperature, and although their concentration is still very low with respect to other compounds, PAHs have a higher impact in tar dew point. This means that the tar remaining after tar cracking at high temperatures is more stable and more prone to condensation than the tar remaining at low temperatures.

The tar composition presented here differs from the tar composition presented in other publications using other types of feedstock such lignite [55], bituminous coal [56], woody biomass [57], sewage sludge [58, 59]. Even compared with other MSW, $[60,61]$ tar composition is very different, mainly due to the MSW composition. However, in most of the studies, naphthalene is among the most abundant tar molecules [57, 58, 59, 60, 62, 63, 64] and the most difficult aromatic compound to be destroyed by thermal cracking, after 
Table 4: Aromatic compounds found during steam and air gasification of MSW. Concentrations are given in $\mu \mathrm{g} / 100 \mathrm{ml}$. ND $=$ Not detected (below the limit of detection)

\begin{tabular}{|c|c|c|c|c|c|}
\hline & Temperature & $800^{\circ} \mathrm{C}$ & $1100^{\circ} \mathrm{C}$ & $800{ }^{\circ} \mathrm{C}$ & $1100^{\circ} \mathrm{C}$ \\
\hline Structure & Gasification agent & Air & Air & Steam & Steam \\
\hline & Benzene & 10.45 & 2.38 & N.D & 5.24 \\
\hline & Toluene & 18.77 & 1.42 & 0.73 & 1.56 \\
\hline & $\mathrm{m} / \mathrm{p}$-Xylene & 2.83 & 0.37 & 1.33 & N.D \\
\hline & o-Xylene & 2.18 & 2.9 & 6.3 & 2.16 \\
\hline & Indan & 0.42 & N.D & 0.32 & 0.04 \\
\hline & Indene & 3.59 & 1.63 & 2.42 & 1.1 \\
\hline & Naphthalene & 6.59 & 13.59 & 4.02 & 5.24 \\
\hline & 2-Methylnaphthalene & 1.91 & 0.24 & 1.37 & 0.13 \\
\hline & 1-Methylnaphthalene & 1.25 & 0.16 & 0.86 & 0.11 \\
\hline & Biphenyl & 0.69 & 0.81 & 0.53 & 0.37 \\
\hline & Acenaphthylene & 1.12 & 3.93 & 0.65 & 1.33 \\
\hline & Acenaphthene & 0.2 & 0.1 & 0.2 & 0.03 \\
\hline & Fluorene & 0.56 & 0.53 & 0.41 & 0.22 \\
\hline & Phenanthrene & 0.73 & 2.53 & 0.49 & 0.87 \\
\hline & Anthracene & 0.23 & 0.54 & 0.16 & 0.2 \\
\hline & Fluoranthene & 0.07 & 1.19 & 0.05 & 0.46 \\
\hline & Pyrene & 0.16 & 1.41 & 0.1 & 0.38 \\
\hline Total tar & (Phenolic + Aromatic) & 51.92 & 33.81 & 20.33 & 19.99 \\
\hline
\end{tabular}


Table 5: Phenolic compounds found during steam and air gasification of MSW. Concentrations are given in $\mu \mathrm{g} / 100 \mathrm{ml}$. ND $=$ Not detected (below the limit of detection).

\begin{tabular}{|l|l|l|l|l|l|}
\hline & Temperature & $800^{\circ} \mathrm{C}$ & $1100^{\circ} \mathrm{C}$ & $800{ }^{\circ} \mathrm{C}$ & $1100^{\circ} \mathrm{C}$ \\
\hline Gasification agent & Air & Air & Steam & Steam \\
\hline & Phenol & 0.13 & 0.08 & 0.13 & 0.55 \\
\hline & o-Cresol & 0.01 & N.D & 0.1 & N.D \\
\hline & 2-Cresol & 0.01 & N.D & N.D & N.D \\
\hline
\end{tabular}

231 benzene $[65,27]$.

\subsection{Plasma cracking experiments}

\subsubsection{Characterisation of the plasma discharges}

The plasma pulses were kept between 70-72 pps (pulses per second) throughout the whole temperature range. The voltage and current pulses shapes were very similar during all discharges. The voltage pulse had an oscillating behavior, with a peak voltage of $20 \mathrm{kV}$, with a duration of $30 \mathrm{~ns}$ 
and two more peaks of a similar duration but characterized by lower voltage. These characteristics can be seen in the voltage-current curves at different temperatures presented in figure 3 .
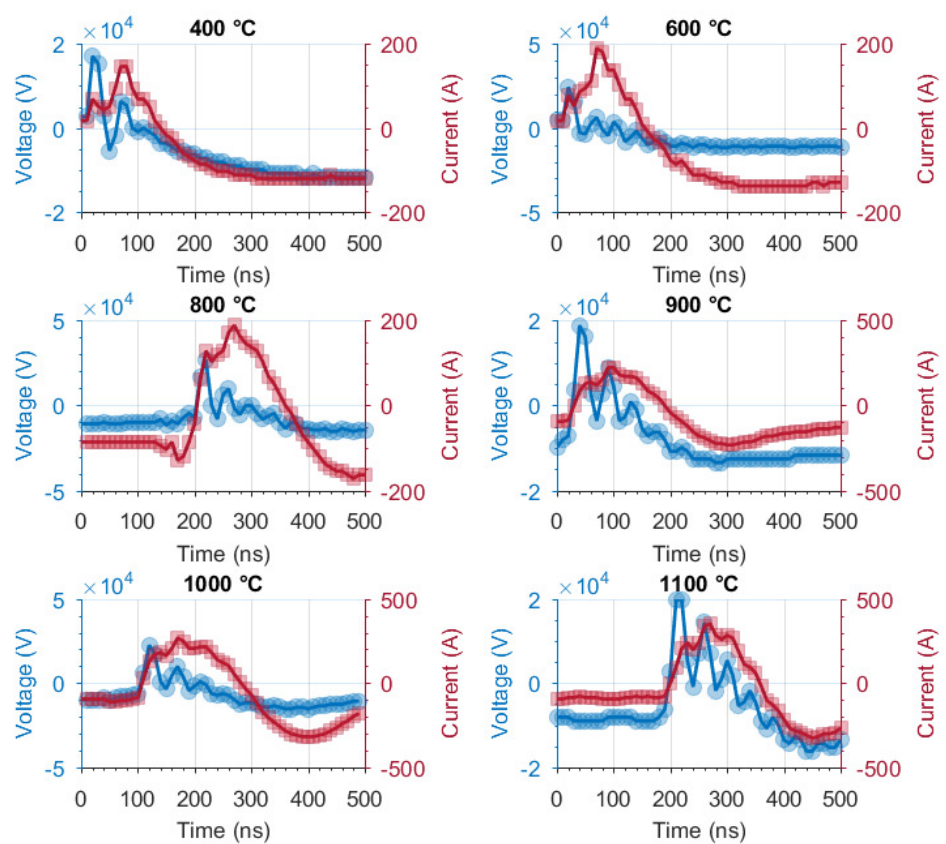

Figure 3: Plasma discharges over nitrogen polluted with naphthalene at different temperatures. Blue represents Voltage and Red represents Current.

t shown in figure 4.

There is a direct proportionality between SEI and temperature, however, it is not clear whether it follows a linear or exponential trend. The evolution 


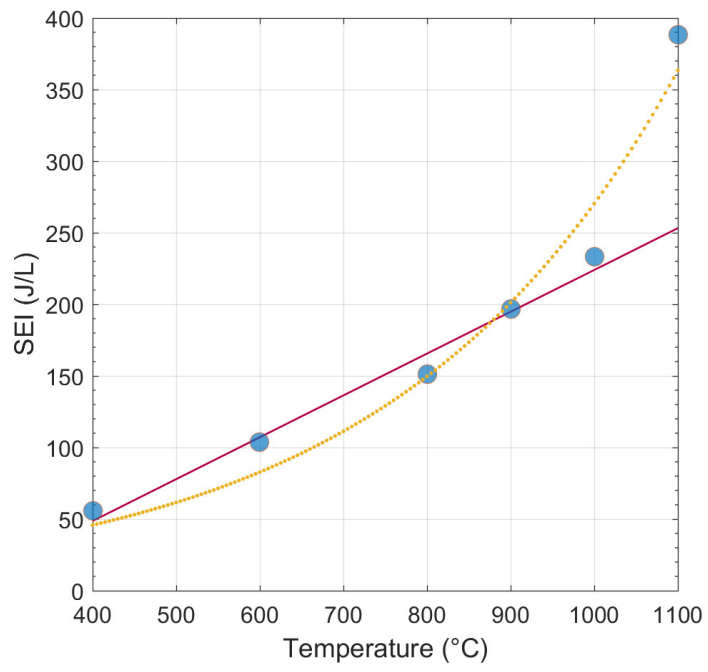

Figure 4: SEI variation with temperature. Points represent experiments, the yellow dotted line is an exponential regression, the red solid line is a linear regression (excluding the last point).

before $1000^{\circ} \mathrm{C}$ suggest a linear dependency ( with a $\mathrm{R}^{2}=0.98$ ) which was also found by other authors $[45,46,66]$ but the high SEI value at $1100^{\circ} \mathrm{C}$ indicates that an exponential trend (with an $\mathrm{R}^{2}=0.95$ ) can also describe this evolution.

\subsubsection{Naphthalene cracking experiments}

The plasma setup, described in the Experimental section and shown in figure 2 is used to crack naphthalene at temperatures between $400^{\circ} \mathrm{C}$ and $1100^{\circ} \mathrm{C}$. The initial concentration of naphthalene was set at $1.6 \mathrm{~g} / \mathrm{Nm}^{3}\left(\mathrm{Nm}^{3}\right.$ refers to Normal cubic meters) or around $300 \mathrm{ppm}$.

These experiments confirm that naphthalene requires temperatures higher than $1000^{\circ} \mathrm{C}$ in order to be fully cracked by thermal cracking. This temperature is slightly lower than the temperatures already reported for naphthalene 
cracking $[15,65]$ due to the longer residence time used in this study together with a possible catalytic effect of the $\mathrm{FeCrAl}$ oxide present in the inner walls of the reactor. The use of plasma reduces this temperature to $800^{\circ} \mathrm{C}$ which means that a clean gas could be obtained by introducing a plasma at a lower temperature. The results of naphthalene cracking are shown in figure 6a, showing a clearer trend than previously published results [67].

An additional observation in figure $6 \mathrm{a}$, which can be confirmed by observing figure $6 \mathrm{~b}$, is that there is a point (around $900{ }^{\circ} \mathrm{C}$ ) where thermal cracking reactions are more extensive than plasma cracking reactions. In figure 6b where energy efficiency(EE) is plotted against temperature, it can be observed that below $800^{\circ} \mathrm{C}$ the EE increases with temperature, but beyond this point, EE drops sharply. This behavior can also be seen in the variation of energy cost $(\beta)$, which varies inversely with $\mathrm{EE}$, showing its lowest value at $800^{\circ} \mathrm{C}$. (see figure 5 ).

An explanation can be found in the fact that up to $800^{\circ} \mathrm{C}$ the amount of naphthalene present in the gas is high enough to allow all (or most of) the reactive plasma species to be consumed by reacting with naphthalene (reaction R2, see next section). Above this point, the naphthalene concentration is reduced mainly by thermal cracking, making the excited species to be consumed by collisions with bulk gas molecules, reactor walls and other excited molecules (reaction R3 and R4, see next section), which consequently reduces the energy efficiency. The EE drop is enhanced by the fact that the SEI increases with temperature. 


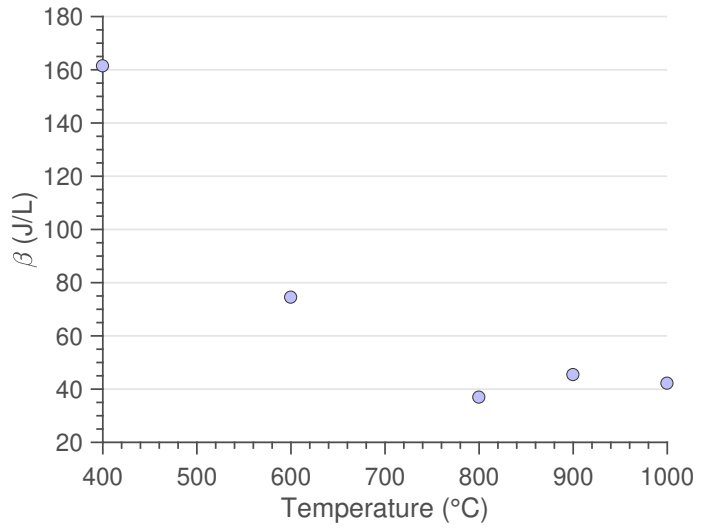

Figure 5: Specific energy cost $\beta$ variation with temperature

\subsubsection{Kinetics of plasma naphthalene cracking}

In order to evaluate the efficiency of the plasma removal process, the 0Dglobal kinetics approach for pollutant removal proposed by Yan et al. [68] is adapted to the nanosecond pulsed naphthalene removal process. According to this approach the naphthalene plasma removal process can be described by the reactions $\mathrm{R} 1$ to $\mathrm{R} 4$. In these reactions $N_{2}^{*}$ represents reactive radicals, and $\mathrm{N}_{2}$ represents the bulk gas, which consists mainly of ground-state nitrogen molecules $\left(N_{2}\left(X^{1} \Sigma_{g}^{+}\right)\right)$

The process starts with reaction $\mathrm{R} 1$ by the production of reactive radicals. The following three reactions represent 3 possible ways in which the reactive radicals can be consumed:

- Reaction R2 represents the radical consumption due to reaction with naphthalene

- Reaction R3 represents the consumption of nitrogen radicals by quenching with bulk gas molecules producing non-reactive radicals that do not react with any naphthalene molecule. 


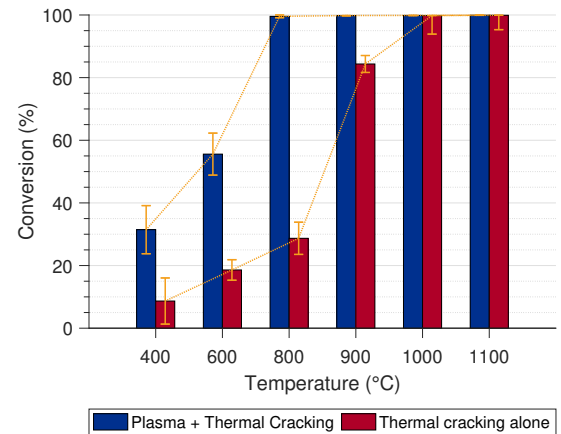

(a) Thermal cracking vs. plasma-enhanced thermal cracking of naphthalene

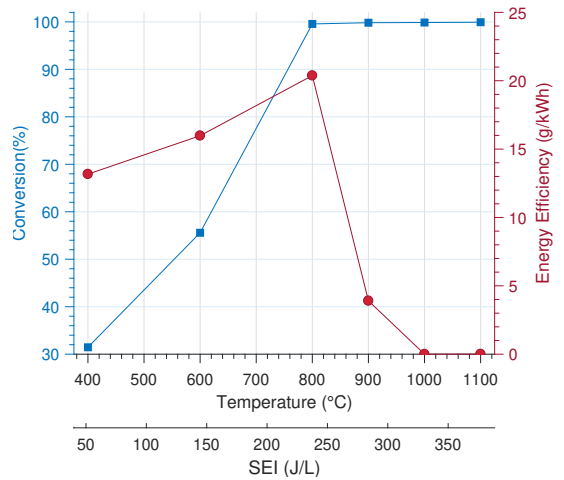

(b) Energy efficiency and plasma-

enhanced thermal conversion vs.

Temperature

Figure 6: Evolution of conversion and energy efficiency (EE) with temperature

$$
\begin{gathered}
\mathrm{C}_{10} \mathrm{H}_{8}+\mathrm{N}_{2}{ }^{*} \longrightarrow \text { products }+\mathrm{N}_{2} \\
\mathrm{~N}_{2}{ }^{*}+\mathrm{N}_{2} \longrightarrow \text { byproducts } \\
\mathrm{N}_{2}{ }^{*}+\mathrm{N}_{2}{ }^{*} \longrightarrow \text { byproducts }
\end{gathered}
$$

302 The main radical leading to tar cracking $\left(\mathrm{N}_{2}^{*}\right)$ is the metastable $\mathrm{N}_{2}\left(\mathrm{~A}^{3} \Sigma\right)$, 303 due to its higher reaction rate [46] and longer lifetime [69, 70]. In addition to this metastable compound, other excited states can help to remove 
naphthalene such $\mathrm{N}_{2}\left(\mathrm{a}^{\prime}{ }^{1} \Sigma_{u}^{-}\right), \mathrm{N}_{2}\left(\mathrm{a}^{1} \Pi_{g}\right), \mathrm{N}_{2}\left(\mathrm{~B}^{3} \Pi_{g}\right)$ and $\mathrm{N}_{2}\left(\mathrm{~B}^{3} \Sigma_{u}^{-}\right)$[51]. Other reactions like excitation of naphthalene due to electron impact are not taken into account in this model due to the small electron cross sections of hydrocarbons together with the small concentration of naphthalene with respect to nitrogen [34].

The plasma naphthalene removal kinetics will depend on the way radicals are consumed. The ideal use of the radicals is the naphthalene removal given by the reaction $\mathrm{R} 2$, while reactions $\mathrm{R} 3$, $\mathrm{R} 4$ lead to inefficiencies.

By making a mass balance over the reactive species $\mathrm{N}_{2}^{*}$, the radical termination due to naphthalene removal and the radical termination due to collisions with bulk gas molecules lead to equations 6 and 7 respectively.

$$
\begin{gathered}
{[C]_{f}-[C]_{o}=k_{1} * S E I} \\
\frac{[C]_{f}}{[C]_{o}}=\exp \left(-\frac{S E I}{\beta}\right)
\end{gathered}
$$

where $[C]_{f}$ and $[C]_{o}$ are expressed in $\mathrm{mol} / \mathrm{L}, k_{1}$ in mol/J and SEI and $\beta$ in $\mathrm{J} / \mathrm{L}$.

The plot of the left side of the above equations with respect to SEI allows to determine which mechanism is followed during the removal process: if there is a linear trend between concentations and SEI, plasma excited species are consumed by naphthalene decomposition while a logaritmic relationship between the ratio of final to initial concentrations and SEI indicates that plasma is consumed by collisions with the bulk gas. The aforementioned graphs are presented in figure 7 , where none of the graphs shows a linear trend, however, comparing the two figures we can distinguish two different 
regions.
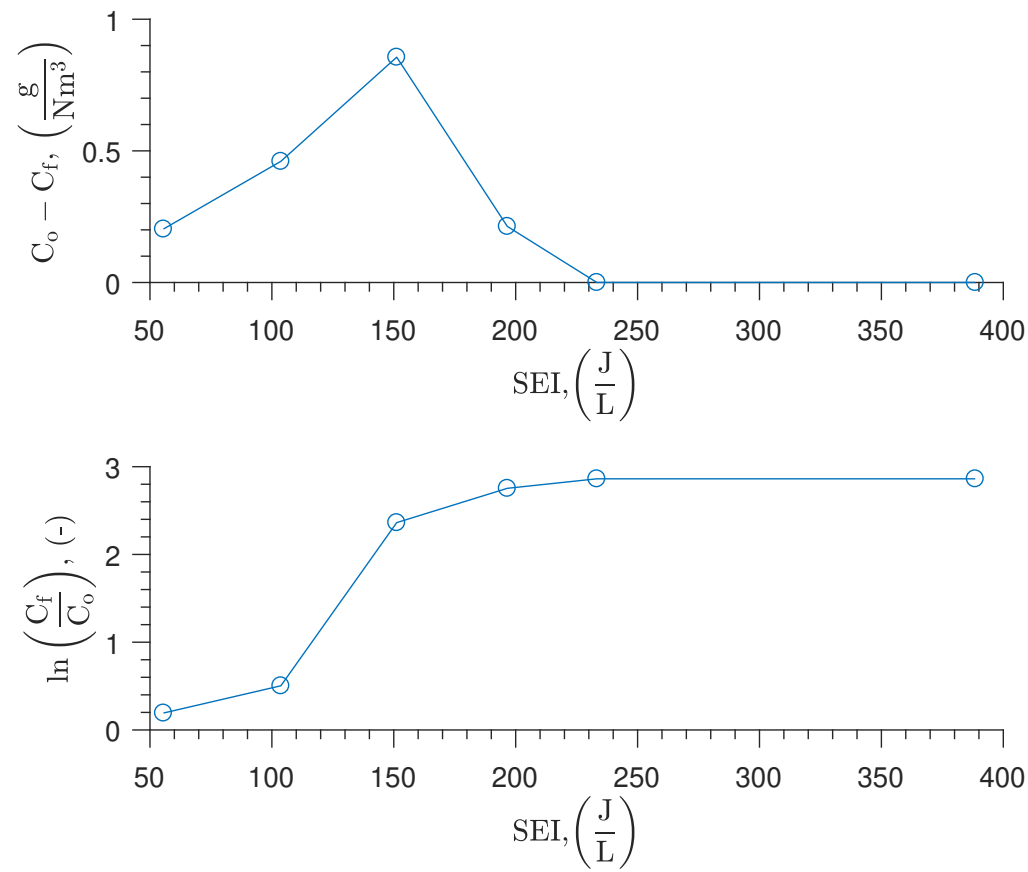

Figure 7: Plasma naphthalene removal with respect to SEI. Upper graph: No linear radical termination kinetics R2. Lower part: Linear radical termination kinetics R3

The first region, below and up to $800^{\circ} \mathrm{C}$ (corresponding to an SEI of 150 $\mathrm{J} / \mathrm{L}$ ) there is a linear proportionality between the concentrations and the SEI in the upper graph of figure 7; this describes that in this region the naphthalene removal is dominated by reactions with plasma reactive species. In the second region, above $800^{\circ} \mathrm{C}$, where there is a logarithmic proportionality between the ratio of concentrations and the SEI in the lower graph of 7; here the plasma reactive species are consumed by collisions with bulk gas molecules, indicating that the reduction of naphthalene concentration is dominated by thermal cracking.

These results suggest that after a specific threshold, in this case $800^{\circ} \mathrm{C}$, 
thermal tar cracking modeling is sufficient to simulate tar removal. This explains why the simulations of other researchers based on thermal cracking only, are sufficient to describe the concentrations of tar after a thermal plasma cleaning unit $[27,28,30]$. However further experiments need to be performed in order to evaluate how the residence time can affect the threshold where thermal cracking is dominant, since the study of Materazzi et al. [28] evidences that at short residence times $(<2 \mathrm{~s})$, the effect of plasma excited species can play a significant role for naphthalene and benzene removal.

\section{Conclusion}

Gasification of MSW is a promising technology for waste treatment and energy valorization, but it is strongly limited by the presence of tar. MSW gasification experiments showed that the most difficult tar compound to be removed by thermal cracking is naphthalene. Naphthalene cracking was then studied under a nanosecond-pulsed (ns-pulsed) plasma unit in a downstream reactor, where total naphthalene removal was achieved at $800^{\circ} \mathrm{C}$ a temperature much lower than the one needed in thermal removal alone, which was around $1000^{\circ} \mathrm{C}$. A maximum energy efficiency was also reached at $800^{\circ} \mathrm{C}$.

A global kinetic model shows that below $800^{\circ} \mathrm{C}$, the main mechanism of plasma excited species consumption is naphthalene cracking, while above this temperature,the main consumption mechanism is through collisions with the bulk gas. From these results, we can expect that with real tar, a temperature well below $800^{\circ} \mathrm{C}$ is needed for complete tar removal using a plasma-aided thermal plasma system since most of the compounds found in tar, with the exception of PAHs heavier than tar, have a cracking temperature much lower 
than the one of naphthalene. The optimal energy efficiency for real tar removal is expected also to shift towards a lower temperature. An opposite trend should be seen for benzene and heavy PAHs molecules like pyrene, which need higher temperatures to be cracked $[65,71]$, expecting to have a lower energy efficiency at a given temperature when compared to naphthalene.

\section{Acknowledgement}

The research leading to these results has received funding from the European Community's Horizon 2020 Programme under Grant Agreement No. 721185 (MSCA-ETN NEW- MINE, https://new-mine.eu/). The main author also wants to thank Peter Colaerts and Dr. Radu Duca for their helpful discussions over the SPA/SPE analysis and Hans Van Eycken and Ivo

Lamberts for their helpful contributions to the mechanical fitting out of the plasma reactor.

\section{References}

[1] J. Fermoso, F. Rubiera, D. Chen, Sorption enhanced catalytic steam gasification process: a direct route from lignocellulosic biomass to high purity hydrogen, Energy Environ. Sci. 5 (2012) 6358-6367. URL: http://dx.doi.org/10.1039/C2EE02593K. doi:10.1039/C2EE02593K.

[2] N. Kamińska-Pietrzak, A. Smoliński, Selected environmental aspects of gasification and co-gasification of various types of waste, Journal of Sustainable Mining 12 (2013) 6 - 13. URL: 
http://www.sciencedirect.com/science/article/pii/S230039601530063X. doi:https://doi.org/10.7424/jsm130402.

[3] M. Hawrot-Paw, A. Koniuszy, M. Mikiciuk, M. Izwikow, T. Stawicki, P. Sedłak, Analysis of ecotoxic influence of waste from the biomass gasification process, Environmental Science and Pollution Research 24 (2017) 15022-15030. URL: https://doi.org/10.1007/s11356-017-9011-8. doi:10.1007/s11356-017-9011-8.

[4] V. S. Sikarwar, M. Zhao, P. Clough, J. Yao, X. Zhong, M. Z. Memon, N. Shah, E. J. Anthony, P. S. Fennell, An overview of advances in biomass gasification, Energy Environ. Sci. 9 (2016) 2939-2977. URL: http://dx.doi.org/10.1039/C6EE00935B. doi:10.1039/C6EE00935B.

[5] Kim, T.,Liu, G, Boaro, M, Lee, S.-I., Vohs, J,Gorte, R, AlMadhi, O,Dabbousi, B, A study of carbon formation and prevention in hydrocarbon-fueled SOFC, Journal of Power Sources 155 (2006)231238. URL: http://dx.doi.org/10.1016/j.jpowsour.2005.05.001. doi:10.1016/j.jpowsour.2005.05.001.

[6] Lorente, E,Millan, M., Brandon, N., Use of gasification syngas in SOFC: Impact of real tar on anode materials. , International Journal of Hydrogen Energy 37 (2012)7271 - 7278. III Iberian Symposium on Hydrogen, Fuel Cells and Advanced Batteries, HYCELTEC2011. URL: http://dx.doi.org/10.1016/j.ijhydene.2011.11.047. doi:10.1016/j.ijhydene.2011.11.047.

[7] Papurello, D.,Lanzini, A., Leone, P, Santarelli, M., Vohs, J,Gorte, R, 
Al-Madhi, O,Dabbousi, B, The effect of heavy tars (toluene and naphthalene) on the electrochemical performance of an anode-supported SOFC running on bio-syngas. , Journal of Power Sources 99 (2016)747 - 753. URL: http://dx.doi.org/10.1016/j.renene.2016.07.029. doi:10.1016/j.renene.2016.07.029.

[8] Subotić, V.,Baldinelli, A.,Barelli, L., Scharler, R., Pongratz, G,Hochenauer, C.,Anca-Couce, A., Applicability of the SOFC technology for coupling with biomass-gasifier systems: Short- and long-term experimental study on SOFC performance and degradation behaviour., Applied Energy 256 (2019). URL: $\quad$ http://dx.doi.org/10.1016/j.apenergy.2019.113904. doi:10.1016/j.apenergy.2019.113904.

[9] Bain, R. L.,Dayton, D. C, Carpenter, D. L., Czernik, S. R., Feik, C. J.,French, R. J., Magrini-Bair, K. A., Phillips, S. D., Evaluation of Catalyst Deactivation during Catalytic Steam Reforming of Biomass-Derived Syngas., Industrial \& Engineering Chemistry Research 44 (2005)7945-7956. URL: http://dx.doi.org/10.1021/ie050098w. doi:doi.org/10.1021/ie050098w.

[10] J. Zhou, H. Ma, F. Jin, H. Zhang, W. Ying, Mn and Mg dual promoters modified $\mathrm{Ni} / \alpha-\mathrm{Al}_{2} \mathrm{O}_{3}$ catalysts for high temperature syngas methanation, Fuel Processing Technology 172 (2018) 225 - 232. URL: http://www.sciencedirect.com/science/article/pii/S0378382017311232. doi:https://doi.org/10.1016/j.fuproc.2017.08.023.

[11] P. Aravind, W. de Jong, Evaluation of high temperature gas cleaning 
options for biomass gasification product gas for solid oxide fuel cells, Progress in Energy and Combustion Science 38 (2012) 737 - 764. URL: http://www.sciencedirect.com/science/article/pii/S0360128512000214. doi:https://doi.org/10.1016/j.pecs.2012.03.006.

[12] S. Anis, Z. Zainal, Tar reduction in biomass producer gas via mechanical, catalytic and thermal methods: A review, Renewable and Sustainable Energy Reviews 15 (2011) 2355 - 2377. URL: http://www.sciencedirect.com/science/article/pii/S1364032111000608. doi:https://doi.org/10.1016/j.rser.2011.02.018.

[13] X. Zeng, F. Wang, Y. Sun, J. Zhang, S. Tang, G. Xu, Characteristics of tar abatement by thermal cracking and char catalytic reforming in a fluidized bed two-stage reactor, Fuel 231 (2018) 18 - 25. URL: http://www.sciencedirect.com/science/article/pii/S0016236118308664. doi:https://doi.org/10.1016/j.fuel.2018.05.043.

[14] A. Warsita, K. Al-attab, Z. Zainal, Effect of water addition in a microwave assisted thermal cracking of biomass tar models, Applied Thermal Engineering 113 (2017) 722 - 730. URL: http://www.sciencedirect.com/science/article/pii/S1359431116332045. doi:https://doi.org/10.1016/j.applthermaleng.2016.11.076.

[15] M. Zhai, X. Wang, Y. Zhang, P. Dong, G. Qi, Y. Huang, Characteristics of rice husk tar secondary thermal cracking, Energy 93 (2015) 1321 - 1327. URL: http://www. sciencedirect. com/science/article/pii/S0360544215013973. doi:https://doi.org/10.1016/j.energy.2015.10.029. 
[16] C. P. Quitete, R. C. P. Bittencourt, M. M. Souza, Coking resistance evaluation of tar removal catalysts, Catalysis Communications 71 (2015) $79-83 . \quad$ URL: http://www.sciencedirect.com/science/article/pii/S1566736715300479. doi:https://doi.org/10.1016/j.catcom.2015.08.013.

[17] D. Meng, Y. Zhang, Z. Wang, X. Qu, J. Gao, T. Jiao, P. Liang, Study on sulfur conversion characteristics in catalytic cracking of coal tar in the presence of dolomitesupported catalysts, Energy \& Fuels 33 (2019) 5102-5109. URL: $\quad$ https://doi.org/10.1021/acs.energyfuels.9b00832. doi:10.1021/acs.energyfuels.9b00832.

[18] G. Guan, M. Kaewpanha, X. Hao, A. Abudula, Catalytic steam reforming of biomass tar: Prospects and challenges, Renewable and Sustainable Energy Reviews 58 (2016) 450 - 461. URL: http://www.sciencedirect.com/science/article/pii/S1364032115016998. doi:https://doi.org/10.1016/j.rser.2015.12.316.

[19] S. Liu, Y. Wang, R. Wu, X. Zeng, S. Gao, G. Xu, Fundamentals of catalytic tar removal over in situ and ex situ chars in two-stage gasification of coal, Energy \& Fuels 28 (2014) 58-66. URL: https://doi.org/10.1021/ef4021153. doi:10.1021/ef4021153. arXiv:https://doi.org/10.1021/ef4021153.

[20] F. Di Gregorio, F. Parrillo, E. Salzano, F. Cammarota, U. Arena, Removal of naphthalene by activated carbons from hot gas, Chemical Engineering Journal 291 (2016) $244-$ 253. URL: 
http://www.sciencedirect.com/science/article/pii/S1385894716300493. doi:https://doi.org/10.1016/j.cej.2016.01.081.

[21] P. Lu, Q. Huang, Y. Chi, F. Wang, J. Yan, Catalytic cracking of tar derived from the pyrolysis of municipal solid waste fractions over biochar, Proceedings of the Combustion Institute 37 (2019) 2673 - 2680. URL: http://www.sciencedirect.com/science/article/pii/S1540748918302347. doi:https://doi.org/10.1016/j.proci.2018.06.051.

[22] Y. Byun, W. Namkung, M. Cho, J. W. Chung, Y.-S. Kim, J.-H. Lee, C.-R. Lee, S.-M. Hwang, Demonstration of thermal plasma gasification/vitrification for municipal solid waste treatment, Environmental Science \& Technology 44 (2010) 6680-6684. URL: https://doi .org/10.1021/es101244u. doi:10.1021/es101244u. arXiv:https://doi.org/10.1021/es101244u, pMID: 20677789.

[23] Y. Byun, M. Cho, J. W. Chung, W. Namkung, H. D. Lee, S. D. Jang, Y.-S. Kim, J.-H. Lee, C.-R. Lee, S.-M. Hwang, Hydrogen recovery from the thermal plasma gasification of solid waste, Journal of Hazardous Materials 190 (2011) 317 - 323. URL: http://www.sciencedirect.com/science/article/pii/S0304389411003554. doi:https://doi.org/10.1016/j.jhazmat.2011.03.052.

[24] M. Hlina, M. Hrabovsky, T. Kavka, M. Konrad, Production of high quality syngas from argon/water plasma gasification of biomass and waste, Waste Management 34 (2014) 63 - 66. URL: http://www.sciencedirect.com/science/article/pii/S0956053X13004522. doi:https://doi.org/10.1016/j.wasman.2013.09.018. 
[25] N. Agon, M. Hrabovsky, O. Chumak, M. Hlina, V. Kopecký, A. Masláni, A. Bosmans, L. Helsen, S. Skoblja, G. V. Oost, J. Vierendeels, Plasma gasification of refuse derived fuel in a single-stage system using different gasifying agents, Waste Management 47 (2016) 246 - 255. URL: http://www.sciencedirect.com/science/article/pii/S0956053X15300313. doi:https://doi.org/10.1016/j.wasman.2015.07.014, refuse Derived Fuel/Solid Recovered Fuel.

[26] A. Sanlisoy, M. Carpinlioglu, A review on plasma gasification for solid waste disposal, International Journal of Hydrogen Energy 42 (2017) 1361 - 1365. URL: http://www.sciencedirect.com/science/article/pii/S0360319916306735. doi:https://doi.org/10.1016/j.ijhydene.2016.06.008.

[27] M. Materazzi, P. Lettieri, L. Mazzei, R. Taylor, C. Chapman, Tar evolution in a two stage fluid bed-plasma gasification process for waste valorization, Fuel Processing Technology 128 (2014) 146 - 157. URL: http://www.sciencedirect.com/science/article/pii/S037838201400280X. doi:https://doi.org/10.1016/j.fuproc.2014.06.028.

[28] M. Materazzi, P. Lettieri, L. Mazzei, R. Taylor, C. Chapman, Reforming of tars and organic sulphur compounds in a plasma-assisted process for waste gasification, Fuel Processing Technology 137 (2015) 259 - 268. URL: http://www.sciencedirect.com/science/article/pii/S0378382015001174. doi:https://doi.org/10.1016/j.fuproc.2015.03.007.

[29] Y. Gómez-Rueda, L. Helsen, The role of plasma in syn- 
gas tar cracking, Biomass Conversion and Biorefinery (2019). URL: https://doi.org/10.1007/s13399-019-00461-x. doi:10.1007/s13399-019-00461-X.

[30] F. Marias, R. Demarthon, A. Bloas, J. Robert-arnouil, Modeling of tar thermal cracking in a plasma reactor, Fuel Processing Technology 149 (2016) 139 - 152. URL: http://www.sciencedirect.com/science/article/pii/S0378382016301400. doi:https://doi.org/10.1016/j.fuproc.2016.04.001.

[31] S. Liu, D. Mei, L. Wang, X. Tu, Steam reforming of toluene as biomass tar model compound in a gliding arc discharge reactor, Chemical Engineering Journal 307 (2017) 793 - 802. URL: http://www.sciencedirect.com/science/article/pii/S1385894716310762. doi:https://doi.org/10.1016/j.cej.2016.08.005.

[32] T. Nunnally, A. Tsangaris, A. Rabinovich, G. Nirenberg, I. Chernets, A. Fridman, Gliding arc plasma oxidative steam reforming of a simulated syngas containing naphthalene and toluene, International Journal of Hydrogen Energy 39 (2014) 11976 - 11989. URL: http://www.sciencedirect.com/science/article/pii/S0360319914016073. doi:https://doi.org/10.1016/j.ijhydene.2014.06.005.

[33] H. Zhang, F. Zhu, X. Li, R. Xu, L. Li, J. Yan, X. Tu, Steam reforming of toluene and naphthalene as tar surrogate in a gliding arc discharge reactor, Journal of Hazardous Materials 369 (2019) 244 - 253. URL: http://www.sciencedirect.com/science/article/pii/S0304389419300925. doi:https://doi.org/10.1016/j.jhazmat.2019.01.085. 
[34] Y. Wang, H. Yang, X. Tu, Plasma reforming of naphthalene as a tar model compound of biomass gasification, Energy Conversion and Management 187 (2019) 593 - 604. URL: http://www.sciencedirect.com/science/article/pii/S0196890419302663. doi:https://doi.org/10.1016/j.enconman.2019.02.075.

[35] X. Kong, H. Zhang, X. Li, R. Xu, I. Mubeen, L. Li, J. Yan, Destruction of toluene, naphthalene and phenanthrene as model tar compounds in a modified rotating gliding arc discharge reactor, Catalysts 9 (2018) 19. URL: http://dx.doi.org/10.3390/catal9010019. doi:10.3390/catal9010019.

[36] D. Mei, Y. Wang, S. Liu, M. Alliati, H. Yang, X. Tu, Plasma reforming of biomass gasification tars using mixed naphthalene and toluene as model compounds, Energy Conversion and Management 195 (2019) 409 - 419. URL: http://www.sciencedirect.com/science/article/pii/S0196890419305412. doi:https://doi.org/10.1016/j.enconman.2019.05.002.

[37] D. Mei, S. Liu, Y. Wang, H. Yang, Z. Bo, X. Tu, Enhanced reforming of mixed biomass tar model compounds using a hybrid gliding arc plasma catalytic process, Catalysis Today 337 (2019) 225 - 233. URL: http://www.sciencedirect.com/science/article/pii/S0920586119302536. doi:https://doi.org/10.1016/j.cattod.2019.05.046, frontiers in Plasma Catalysis (ISPCEM 2018).

[38] F. Saleem, K. Zhang, A. P. Harvey, Decomposition of benzene as a tar analogue in $\mathrm{CO}_{2}$ and $\mathrm{H}_{2}$ carrier gases, using a non-thermal 
plasma, Chemical Engineering Journal 360 (2019) 714 - 720. URL: http://www.sciencedirect.com/science/article/pii/S1385894718324288. doi:https://doi.org/10.1016/j.cej.2018.11.195.

[39] Z. Wu, J. Wang, J. Han, S. Yao, S. Xu, P. Martin, Naphthalene decomposition by dielectric barrier discharges at atmospheric pressure, IEEE Transactions on Plasma Science 45 (2017) 154-161. doi:10.1109/TPS.2016.2632154.

[40] L. Liu, Q. Wang, S. Ahmad, X. Yang, M. Ji, Y. Sun, Steam reforming of toluene as model biomass tar to $\mathrm{H}_{2}$-rich syngas in a dbd plasma-catalytic system, Journal of the Energy Institute 91 (2018) 927 - 939. URL: http://www.sciencedirect.com/science/article/pii/S1743967117305755. doi:https://doi.org/10.1016/j.joei.2017.09.003.

[41] S. Liu, D. Mei, M. Nahil, S. Gadkari, S. Gu, P. Williams, X. Tu, Hybrid plasma-catalytic steam reforming of toluene as a biomass tar model compound over $\mathrm{Ni} / \mathrm{Al}_{2} \mathrm{O}_{3}$ catalysts, Fuel Processing Technology 166 (2017) 269 - 275. URL: http://www.sciencedirect.com/science/article/pii/S0378382017304952. doi:https://doi.org/10.1016/j.fuproc.2017.06.001.

[42] L. Liu, Q. Wang, J. Song, S. Ahmad, X. Yang, Y. Sun, Plasma-assisted catalytic reforming of toluene to hydrogen rich syngas, Catalysis Science \& Technology 7 (2017) 4216-4231. URL: http://dx.doi.org/10.1039/C7CY00970D. doi:10.1039/C7CY00970D.

[43] R. Cimerman, D. Račková, K. Hensel, Tars removal by non-thermal 
plasma and plasma catalysis, Journal of Physics D: Applied Physics 51 (2018). doi:10.1088/1361-6463/aac762.

[44] L. Liu, Y. Liu, J. Song, S. Ahmad, J. Liang, Y. Sun, Plasma-enhanced steam reforming of different model tar compounds over ni-based fusion catalysts, Journal of Hazardous Materials 377 (2019) 24 - 33. URL: http://www.sciencedirect.com/science/article/pii/S0304389419305527. doi:https://doi.org/10.1016/j.jhazmat.2019.05.019.

[45] S. Nair, K. Yan, A. Pemen, G. Winands, F. van Gompel, H. van Leuken, E. van Heesch, K. Ptasinski, A. Drinkenburg, A high-temperature pulsed corona plasma system for fuel gas cleaning, Journal of Electrostatics 61 (2004) 117 - 127. URL: http://www.sciencedirect.com/science/article/pii/S0304388604000397. doi:https://doi.org/10.1016/j.elstat.2004.02.002.

[46] V. A. Bityurin, E. A. Filimonova, G. V. Naidis, Simulation of naphthalene conversion in biogas initiated by pulsed corona discharges, IEEE Transactions on Plasma Science 37 (2009) 911-919. doi:10.1109/TPS.2009.2019756.

[47] F. Saleem, K. Zhang, A. Harvey, Temperature dependence of non-thermal plasma assisted hydrocracking of toluene to lower hydrocarbons in a dielectric barrier discharge reactor, Chemical Engineering Journal 356 (2019) 1062 - 1069. URL: http://www.sciencedirect.com/science/article/pii/S1385894718315171. doi:https://doi.org/10.1016/j.cej.2018.08.050. 
[48] L. Devi, K. J. Ptasinski, F. J. Janssen, S. V. van Paasen, P. C. Bergman, J. H. Kiel, Catalytic decomposition of biomass tars: use of dolomite and untreated olivine, Renewable Energy 30 (2005) 565 - 587. URL: http://www.sciencedirect.com/science/article/pii/S0960148104002927. doi:https://doi.org/10.1016/j.renene.2004.07.014.

[49] L. P. L. M. Rabou, R. W. R. Zwart, B. J. Vreugdenhil, L. Bos, Tar in biomass producer gas, the Energy Research Centre of the Netherlands (ECN) experience: An enduring challenge, Energy \& Fuels 23 (2009) 6189-6198. doi:10.1021/ef9007032.

[50] C. Brage, Q. Yu, G. Chen, K. Sjöström, Use of amino phase adsorbent for biomass tar sampling and separation, Fuel 76 (1997) 137 - 142. URL: http://www.sciencedirect.com/science/article/pii/S0016236196001998. doi:https://doi.org/10.1016/S0016-2361(96)00199-8.

[51] A. A. Abdelaziz, T. Seto, M. Abdel-Salam, Y. Otani, Influence of nitrogen excited species on the destruction of naphthalene in nitrogen and air using surface dielectric barrier discharge, Journal of Hazardous Materials 246-247 (2013) 26 - 33. URL: http://www.sciencedirect.com/science/article/pii/S0304389412011703. doi:https://doi.org/10.1016/j.jhazmat.2012.12.005.

[52] M. Redolfi, N. Blin-Simiand, X. Duten, S. Pasquiers, K. Hassouni, Naphthalene oxidation by different non-thermal electrical discharges at atmospheric pressure, Plasma Science and Technology 21 (2019) 055503. doi:10.1088/2058-6272/ab01c7. 
[53] G. Ravenni, O. Elhami, J. Ahrenfeldt, U. Henriksen, Y. Neubauer, Adsorption and decomposition of tar model compounds over the surface of gasification char and active carbon within the temperature range $250-800^{\circ} \mathrm{c}$, Applied Energy 241 (2019) 139 - 151. URL: http://www.sciencedirect.com/science/article/pii/S0306261919304313. doi:https://doi.org/10.1016/j.apenergy.2019.03.032.

[54] J. Zeng, J. Hu, Y. Qiu, S. Zhang, D. Zeng, R. Xiao, Multi-function of oxygen carrier for in-situ tar removal in chemical looping gasification: Naphthalene as a model compound, Applied Energy 253 (2019) 113502. URL: http://www.sciencedirect.com/science/article/pii/S0306261919311766. doi:https://doi.org/10.1016/j.apenergy.2019.113502.

[55] W. Yu, S. Han, Z. Lei, K. Zhang, J. Yan, Z. Li, H. Shui, S. Kang, Z. Wang, S. Ren, C. Pan, The reaction behavior of volatiles generated from lignite pyrolysis, Fuel 244 (2019) 22 - 30. URL: http://www.sciencedirect.com/science/article/pii/S0016236119301851. doi:https://doi.org/10.1016/j.fuel.2019.01.185.

[56] Q. Zhou, Q. Liu, L. Shi, Y. Yan, J. Wu, C. Xiang, T. Wang, Z. Liu, Effect of volatiles' reaction on composition of tars derived from pyrolysis of a lignite and a bituminous coal, Fuel 242 (2019) 140 - 148. URL: http://www.sciencedirect.com/science/article/pii/S0016236119300067. doi:https://doi.org/10.1016/j.fuel.2019.01.005.

[57] M. Kuba, H. Hofbauer, Experimental parametric study on product gas and tar composition in dual fluid bed gasification of 
woody biomass, Biomass and Bioenergy 115 (2018) 35 - 44. URL: http://www.sciencedirect.com/science/article/pii/S0961953418300965. doi:https://doi.org/10.1016/j.biombioe.2018.04.007.

[58] T.-Y. Mun, B.-S. Kang, J.-S. Kim, Production of a producer gas with high heating values and less tar from dried sewage sludge through air gasification using a two-stage gasifier and activated carbon, Energy \& Fuels 23 (2009) 3268-3276. URL: https://doi.org/10.1021/ef900028n. doi:10.1021/ef900028n. arXiv:https://doi.org/10.1021/ef900028n.

[59] Q. Jin, X. Wang, S. Li, H. Mikulčić, T. Bešenić, S. Deng, M. Vujanović, H. Tan, B. M. Kumfer, Synergistic effects during co-pyrolysis of biomass and plastic: Gas, tar, soot, char products and thermogravimetric study, Journal of the Energy Institute 92 (2019) 108 - 117. URL: http://www.sciencedirect.com/science/article/pii/S1743967117307122. doi:https://doi.org/10.1016/j.joei.2017.11.001.

[60] A. Veksha, A. Giannis, G. Yuan, J. Tng, W. P. Chan, V. W.C. Chang, G. Lisak, T.-T. Lim, Distribution and modeling of tar compounds produced during downdraft gasification of municipal solid waste, Renewable Energy 136 (2019) 1294 - 1303. URL: http://www.sciencedirect.com/science/article/pii/S0960148118311819. doi:https://doi.org/10.1016/j.renene.2018.09.104.

[61] M. Irfan, A. Li, L. Zhang, M. Wang, C. Chen, S. Khushk, Production of hydrogen enriched syngas from municipal solid waste 
gasification with waste marble powder as a catalyst, International Journal of Hydrogen Energy 44 (2019) 8051 - 8061. URL: http://www.sciencedirect.com/science/article/pii/S0360319919306329. doi:https://doi.org/10.1016/j.ijhydene.2019.02.048.

[62] C. Block, A. Ephraim, E. Weiss-Hortala, D. P. Minh, A. Nzihou, C. Vandecasteele, Co-pyrogasification of plastics and biomass, a review, Waste and Biomass Valorization 10 (2019) 483-509. URL: https://doi .org/10.1007/s12649-018-0219-8. doi:10.1007/s12649018-0219-8.

[63] G. Lopez, A. Erkiaga, M. Amutio, J. Bilbao, M. Olazar, Effect of polyethylene co-feeding in the steam gasification of biomass in a conical spouted bed reactor, Fuel 153 (2015) 393 - 401. URL: http://www.sciencedirect.com/science/article/pii/S0016236115002872. doi:https://doi.org/10.1016/j.fuel.2015.03.006.

[64] M. Cortazar, J. Alvarez, G. Lopez, M. Amutio, L. Santamaria, J. Bilbao, M. Olazar, Role of temperature on gasification performance and tar composition in a fountain enhanced conical spouted bed reactor, Energy Conversion and Management 171 (2018) 1589 - 1597. URL: http://www.sciencedirect.com/science/article/pii/S0196890418306812. doi:https://doi.org/10.1016/j.enconman.2018.06.071.

[65] A. Jess, Mechanisms and kinetics of thermal reactions of aromatic hydrocarbons from pyrolysis of solid fuels, Fuel 75 (1996) 1441 - 1448. URL: http://www. sciencedirect.com/science/article/pii/0016236196001366. doi:https://doi.org/10.1016/0016-2361(96)00136-6. 
[66] E. A. Filimonova, Y. ho Kim, S. H. Hong, Y.-H. Song, Multiparametric investigation on NOxremoval from simulated diesel exhaust with hydrocarbons by pulsed corona discharge, Journal of Physics D: Applied Physics 35 (2002) 2795-2807. doi:10.1088/0022-3727/35/21/316.

[67] Y. Gómez-Rueda, I. Nuran Zaini, W. Yang, L. Helsen, Landfill solid waste-based syngas purification by a hybrid pulsed corona plasma unit, 27th European Biomass Conference and Exhibition, 27-30 May 2019, Lisbon, Portugal (2019) 520 - 522. doi:10.5071/27thEUBCE20192BO.6.2.

[68] K. Yan, E. J. M. van Heesch, A. J. M. Pemen, P. A. H. J. Huijbrechts, From chemical kinetics to streamer corona reactor and voltage pulse generator, Plasma Chemistry and Plasma Processing 21 (2001) 107-137. URL: https://doi.org/10.1023/A:1007045529652. doi:10.1023/A:1007045529652.

[69] A. M. Wróbel, I. Błaszczyk, A. Walkiewicz-Pietrzykowska, A. Tracz, J. E. Klemberg-Sapieha, T. Aoki, Y. Hatanaka, Remote hydrogennitrogen plasma chemical vapor deposition from a tetramethyldisilazane source. part 1. mechanism of the process, structure and surface morphology of deposited amorphous hydrogenated silicon carbonitride films, Journal of Materials Chemistry 13 (2003) 731-737. URL: http://dx.doi .org/10.1039/B211415C. doi:10.1039/B211415C.

[70] Y. Choi, J. Kim, Y. Hwang, One-dimensional discharge simulation of nitrogen dbd atmospheric pressure plasma, Thin Solid Films 506-507 (2006) 389 - 395. URL: 
http://www.sciencedirect.com/science/article/pii/S004060900501299X. doi:https://doi.org/10.1016/j.tsf.2005.08.103, 7th Asia Pacific Conference on Plasma Science and Technology (APCPST) and 17th Symposium on Plasma Science for Materials (SPSM).

[71] R. Pujro, M. Falco, U. Sedran, Catalytic cracking of heavy aromatics and polycyclic aromatic hydrocarbons over fluidized catalytic cracking catalysts, Energy \& Fuels 29 (2015) 1543-1549. URL: https://doi .org/10.1021/ef502707w. doi:10.1021/ef502707w. arXiv:https://doi.org/10.1021/ef502707w. 